\title{
Media Ecology: Exploring the Metaphor to Expand the Theory
}

\author{
Carlos A. Scolari, Ph. D. \\ Universitat Pompeu Fabra
}

\begin{abstract}
This article introduces media ecology and reflects on its potential usefulness for gaining an understanding of the contemporary mutations of the media system. The first section maps the origins of the field, specifically the development of the ecological metaphor. The second section explores the metaphor by including the concepts of evolution, interface and hybridization in the media ecology discourse. The concept of evolution creates a theoretical framework for studying the history of media and suggests new concepts and questions about media extinction, survival and coevolution. The concept of interface focuses on the media, subject and social interactions. Finally, the analysis of media hybridizations is basic for understanding the appearance of new media that combine different devices, languages and functions.
\end{abstract}

Keywords: media ecology, evolution, interface, hybridization, coevolution, media theory 


\section{Understanding media ecology}

In the last decade media ecology has become consolidated as an innovative and useful theoretical framework for media studies. It was born in the 1960 s and was initially ignored ${ }^{1}$ by the scientific establishment; however, the creation of the Media Ecology Association in 1998, the diffusion of the World Wide Web and the development of media convergence processes - which renewed the interest in an integrated approach to media - facilitated the 'resurrection' of thinkers like Marshall McLuhan and the institutional consolidation of media ecology in the context of communication studies and the social sciences. ${ }^{2}$ Even if the Canadian media thinker played a fundamental role in the constitution of the field, for Strate media ecology 'is more than McLuhanism' (2008: 130), and its roots can be traced to the studies of researchers like L. Mumford, J. Ellul, E. Havelock, W. Ong, J. Goody, L. Febvre, H.-J. Martin, E. Eisenstein; H. Innis, E. T. Hall, E. Carpenter, J. Carey, A. Korzybski, S. Langer, D. Lee, and N. Postman (Lum, 2006; Strate 2008). In Kafka and His Precursors Jorge Luis Borges wrote that 'every writer creates his own precursors. His work modifies our conception of the past, as it will modify the future' (1964: 199). In this sense we could say that many researchers were McLuhanian before McLuhan, in the same way that many writers were Kafkian before Kafka. As we can see, media ecology has deep roots in $20^{\text {th }}$ century economy, history, linguistics, sociology and education research. Media ecologists have situated themselves within this multidisciplinary tradition, thus creating a retroactive theoretical framework that supports their contemporary investigations.

A small mystery surrounds the origin of media ecology metaphor. Postman introduced 
it in a conference at the National Council of Teachers of English in 1968. Nevertheless, Postman recognized that McLuhan had employed the concept years before in a personal communication (Lum, 2006: 9). The idea of considering the relationship between media and individuals from an ecological perspective was very probably part of the conversations ${ }^{3}$ held by this group of scholars in the 1960s. In his conference, Postman defined media ecology as 'the study of media as environments', and three years later he created the first media ecology program at the New York University.

Any presentation of the first generation of media ecologists should include a reference to James Carey's contributions. Carey was a scholar who created bridges between the media ecology tradition (specifically the works of Mumford, McLuhan and Innis) and cultural studies thinkers like Clifford Geertz. Carey's classic research of the importance of the telegraph in the American cultural experience is a good example of his contributions to an ecological approach to media and culture (Carey, 1989; Flayhan, 2001; Strate, 2007).

\section{Definitions}

One of the first steps in any scientific field is to define the basic concepts that will permit a consistent discourse to be developed. In this case, to theorize about media ecology means, at least, discussing about concepts such as environments, media, human beings and interactions. For Postman, environments structure what we can see, say and do. They also assign roles and pressure us to play them. Media environments specify what we can do and what we can't. In the case of media environments like books, radio, film, television, etc. the 
technological specifications are more often implicit and informal, and therefore the objective of media ecology -according to Postman- is to make them explicit. Media ecology tries to find out what roles media force us to play, how media structure what we are seeing or thinking, why media make us feel and act as we do. It is in this context that Postman affirmed that media ecology is 'the study of media as environments' (Postman, 1970) and went on to develop the ecological metaphor in diverse texts and circumstances. In a talk delivered in Denver in March 1998 (Five Things We Need to Know About Technological Change) he said that 'technological change is not additive; it is ecological'. He explained this concept with an example: 'A new medium does not add something; it changes everything. In the year 1500, after the printing press was invented, you did not have old Europe plus the printing press. You had a different Europe' (Postman, 1998).

Scholars like McLuhan also insisted that media are environments or a medium in which individuals live like fish do in water. This environment is the place where we create and raise technologies - from writing to television, from wheels to airplanes, from papyrus to books - that later model our perceptual and cognitive systems. In 1977 McLuhan explained that media ecology 'means arranging various media to help each other so they won't cancel each other out, to buttress one medium with another. You might say, for example, that radio is a bigger help to literacy than television, but television might be a very wonderful aid to teaching languages. And so you can do some things on some media that you cannot do on others' (2004: 271). Other scholars like Nystrom affirmed that media ecology should be broadly defined as the study of 'complex communication systems as 
environments' (1973: 1). ${ }^{4}$

\section{Metaphors, ecology and scientific discourse}

Researchers have demonstrated that metaphors are more than a poetic ornament of the language or just a series of rhetorical forms. Rather, they are basic cognitive devices of human communication and culture (Ortony, 1979; Lakoff \& Johnson, 1980). Metaphors are fundamental for understanding the world that surrounds us, and they occupy a central role in our conception of technologies. ${ }^{5}$ But metaphors are not only important for everyday conversations or understandings: they also play a fundamental role in scientific discourse. Many new paradigms or complex theoretical models were born or are represented through metaphors. These rhetorical devices are very useful for giving meaning to new phenomena that are otherwise almost impossible to interpret. Metaphors generate categories, organize processes and establish oppositions and hierarchies.

Communication theories are no exception when it comes to the scientific appropriation of metaphors. It is not difficult to identify the use of metaphors in the communication theories discourse, for example the hypodermic-needle concept during the first period of mass communication research (Shannon \& Weaver, 1949; Wolf, 1985; De Fleur and Ball-Rokeach, 1989) or Noelle-Neumann's spiral of silence (Noelle-Neumann, 1993).

Metaphors are very useful in the constitution of a new research field. The metaphor provides a model for understanding the new territory, offers a vocabulary and indicates in 
which directions to continue exploring. At the same time, the metaphor often facilitates the transmission of a new concept to researchers and the general public: in the 1880s bacteria became a metaphor that articulated the fears about all invisible enemies, be they military, social or economic (Otis, 1999: 94). Many people finally understood Albert Einstein’s theory of relativity after a metaphorical explanation was given: 'Sit with a pretty woman for an hour, and it'll seem like a minute. But sit on a hot stove for a minute, and it'll seem like an hour'.

When a theory is consolidated - 'normal science' for Khun (1962) - the metaphor that was present at its origins is completely integrated into the paradigm: the metaphor becomes invisible. But progress in normal science may reveal anomalies, facts that are difficult to explain within the context of the existing paradigm. This is when the metaphor shows its limits. The accumulation of anomalies may lead to a crisis for the paradigm and the search for new metaphors. For Kuhn, this is the 'revolutionary science' phase, that is, the search for a new model based on a different metaphor.

Why the ecological metaphor? The publication of Fundamentals of Ecology (Odum and Odum, 1953) introduced a new vision of ecological principles characterized by a holistic approach to biological systems. The book proposed a whole-to-part progression: the ecosystem level was the first rather than the last chapter of the book. E. P. Odum (1964) defined this phase of the ecological reflection as the 'new ecology'. As the environmentawareness movement began to emerge in the late 1960s - the first Earth Day was organized on 22 April, 1970 (Dann, 1999) - these ideas spread throughout American society and other 
scientific fields like sociology, economy and linguistics. Media ecology was consolidated in parallel with the consolidation of Odum's new ecology.

What's the 'new ecology'? For E. P. Odum science should not only seek to understand phenomena by detailed study of smaller and smaller components: it should also be synthetic and holistic, in the in the sense of 'seeking to understand large components as functional wholes' (1977: 1289). The rise of the new ecology was a response to the need for greater attention to holism in science and technology. Working in the same direction, after years of thinking about communication processes from a lineal perspective based on the Shannon and Weaver model - in which the information was an arrow flying from the sender to the receiver (1949) - the media ecology scholars proposed a new conception of the relationships between media, individuals and society based on a different metaphor.

The convergence of media studies and ecology situates media ecology at the same level as many other compound metadisciplines, such as biochemistry, psychobiology, linguistic anthropology, and psycholinguistics. This convergence is not causal or an isolated phenomena. The following table shows how researchers from the social sciences and humanities had an open attitude towards ecological and biological models over the post-war years.

\section{Table 1} Application of the ecological and biological metaphors to the social sciences and humanities. 
extraordinary scientific event. The configuration of media ecology in the 1960s and 1970s was part of a broader process of the general application of the ecological metaphor to the social sciences and humanities in the post-war period. Even if the introduction of the ecological metaphor into media studies is not recent, I consider that the analogy has not been completely exploited in the past. A deeper exploration of the metaphor would enlarge our research horizons, increase the number of concepts and categories available for our theoretical conversations and introduce new questions and challenges to media studies.

\section{Interpretations (I): Media as environments}

Media ecology can be simplified to a basic statement: technologies - in our case, communication technologies, from writing to digital media - create environments that affect the people that use them. Let's remember Postman's definition: "the word "ecology" implies the study of environments: their structure, content, and impact on people' (1970). As McLuhan explained in Understanding Media the effects of technology 'do not occur at the level of opinions or concepts, but alter sense ratios or patterns of perception steadily and without any resistance' (2003: 31). For example television 'has changed our sense-lives and our mental processes' (439). Postman amplified this idea when he described how our 'world view' is a creation of every medium of communication. According to Postman each medium provides a 'new orientation for thought, for expression, for sensibility [...] (they) classify the world for us, sequence it, enlarge it, reduce it, color it, argue a case for what the world is like' (1985: 10). This interpretation of the ecological metaphor could be defined as 
the environmental dimension of media ecology. In this interpretation media create an 'environment' that surrounds the individual and models their perception and cognition.

\section{Interpretations (II): Media as species}

Other members of the media ecology tradition like Innis developed a holistic approach that integrated the evolution of the different media and socio-economic processes, for example the parallel development of railroads and telegraphy in the $19^{\text {th }}$ century. For Innis the relation between media is a basic component of his conception of the communication system: the competition between media (book/newspapers, newspapers/radio, etc.) is central to his reflections, for example 'the monopoly of knowledge centering around stone and hieroglyphics was exposed to competition from papyrus as a new and more efficient medium' (2003: 35).

In Amusing Ourselves to Death Postman described the synergies and conflicts between different media in the United States (i.e. telegraph/press) and the central role of television in the media ecology: 'through it (TV) we learn what telephone system to use, what movies to see, what books, records and magazines to buy, what programs to listen to' (1985: 78). This second approach can also be identified in McLuhan's tetrads (McLuhan \& McLuhan, 1992) and in many passages of his books, especially Understanding Media. According to McLuhan 'media interact among themselves. Radio changed the form of the news story as much as it altered the film image in the talkies. TV caused drastic changes in radio programming, and in the form of the thing or documentary novel' (2003: 78). 
Nystrom reaffirmed this perspective when she wrote that "no medium of communication operates in isolation. Every medium affects every other medium' (1973: 130). McLuhan summarized this second conception of the ecological metaphor in one of his famous aphorisms: 'No medium has its meaning or existence alone, but only in constant interplay with other media' (2003: 43). This interpretation of the ecological metaphor could be defined as the intermedia dimension of media ecology. In this interpretation media are like 'species' that live in the same ecosystem and establish relationships between each other.

In a few words: the ecological metaphor applied to media accepts at least two complementary interpretations. The environmental conception considers the media to be an environment that surrounds the subjects and models their cognitive and perceptual system. The intermedia version of the metaphor looks at the interactions between media, as if they were species of an ecosystem. Can both interpretations of the metaphor be integrated into a single framework? In this case we should consider media ecology as an environment that includes different media and technologies (i.e. television, radio, the Internet, RFIDs, mobile devices, TCP/IP protocol, etc.), subjects (i.e. content producers, users, readers, media researchers, etc.) and the social/political forces (Hollywood majors, Wikileaks, legal regimes, etc.).

This integrated conception of media ecology is closed to approaches like the Social Construction of Technology (SCOT) (Hughes, 1983; Bijker, Hughes \& Pinch 1987; Bijker \& Law, 1992; Bijker, 1997) and the Actor-Network Theory (ANT) (Latour, 1987, 2005; Law \& Hassard, 1999) (see also Johnson \& Wetmore, 2009). SCOT holds that technology 
is shaped by the interactions between engineers, organizations, market forces, government policies and consumers (individuals and groups). ANT is a more radical approach that dissolves the differences between humans and technologies, and combines material and semiotic elements in a single network of relationships. From the perspective of ANT the interactions in a media environment involve professionals, managers, consumers, media contents, strategies, technologies (such as cameras, screens, transmitters, antennas), etc. I'll return to these potentially worthwhile connections between media ecology, SCOT and ANT when I analyze the role of interfaces in the last section.

\section{Extending the metaphor}

Exploring a scientific metaphor means, among other possibilities, analyzing the semantic universe of the analogy, translating the basic assumptions from one field to another to check the strength of the metaphor and identify new questions and scientific challenges. The theoretical road I propose here is in the same line as Logan's approach to media ecology (2004, 2007a, 2007b). According to Logan 'to date media ecology has focused on the environment in which media operate without exploring at a deep level the implications of the biological nature of ecology' (2007b: 1). Mostly based on the contributions of McLuhan (1962, 1964), Christiansen (1994; Christiansen et al., 2002) and Kauffman (2000), Logan's position integrates technology, media, language and culture in a unified ecology: 'media and technologies like languages and cultures evolve in a manner very similar to that of biotic organisms. Now we are in a position to talk about media 
ecology as the study of the interactions of agents acting as organisms' (2007b: 12).

To explore the media ecology metaphor does not mean automatically transferring concepts and categories from biology to media studies; it means visualizing new questions and challenges for media studies taking the dialogue with the ecological and evolutionary traditions as a starting point. In other words, the objective of this article is not to propose another 'theory of everything' but to expand media studies by introducing a series of keywords from the evolutionary and ecological research fields. This approach is not completely original: studies on the evolution of the Internet have presented a 'natural lifecycle model of new media development' (Lehman-Wilzig \& Cohen-Avigdor, 2004), and researchers like Dimmick have introduced the concept of niche into the analysis of media competition. $^{6}$

In this article I will limit my theoretical exploration to a short list of concepts that could open new paths for media research: evolution, interface and hybridization.

\section{Evolution}

Ecology is the scientific study of organisms and their interactions with the environment. In this context an ecological approach focuses on the distributions, abundances and relations between organic and non-organic beings in an ecosystem. ${ }^{7}$ In other words, ecology studies the web or network of relations among organisms at different scales of organization, from a bacterial community to the Amazon rainforest. Ecology is closely related to other fields and disciplines, like physiology, behavioral sciences, genetics 
and, the most important for our discourse, evolution studies. As every student knows, Charles Darwin (1975) developed a comprehensive model of biological evolution in his seminal book On the Origin of Species (1859). Organic species undergo mutations changes in their genetic material - caused by copying errors during cell division due to exposure to radiation, chemical mutagens, viruses, or generated by the organism itself. In recent years human manipulation of genetic material has also contributed to this process. Mutation is an essential source of variation, which represents the emergence of a new individual in an ecosystem.

The complete title of the first edition of Darwin's book was On the Origin of Species by Means of Natural Selection, or the Preservation of Favoured Races in the Struggle for Life. Darwin realized that ecosystem populations cannot expand indefinitely because the resources are limited. Therefore, the new individuals must compete for survival with the old ones. If the mutation assists the organism to survive, the individual will adapt to the environment and reproduce; if not, it will be eliminated by natural selection. Most mutations are deleterious; evolution progresses through the few individuals that are favorable. When a species generates a new branch, biologists talk about a bifurcation or forking process.

Evolution theory analyzes the change in the inherited traits of a population of organisms through multiple generations. If the ecological approach studies the network of relations between organisms at the same time, then the evolutionary approach investigates the diversification of these organisms into new species, the extinction of species 
(macroevolution) and the smaller changes such as adaptations (microevolution). In other words, while the ecologist reconstructs webs of organisms, the evolutionary scholar draws trees of life. Or, in another sense, we can also say that ecology thinks in space and evolution thinks in time. Both conceptions - ecology and evolution - are complementary and can be reorganized following the traditional linguistic opposition between diachronic/synchronic levels.

The intersection of ecology and evolutionary biology defines a scientific field called evolutionary ecology. This field not only considers the evolution of individual species (the trees of life) but the interactions between them. The main areas of intervention of evolutionary ecology are life history evolution, the extinction and creation of new species, the evolution of relations (cooperation, predator-prey interactions, parasitism, mutualism, coevolution) and the general evolution of biodiversity and communities.

Charles Darwin never employed the concepts of evolution or ecosystem in On the Origin of Species. However, he laid the foundations for an integrated theory of evolution and wrote many pages on species, variety, diversity, extinction, and - possibly the key concept of his theory - natural selection. Over the last 150 years Darwinian ideas have permeated the social sciences and humanities. Many researchers and specialists have applied Darwin's model to the evolution of technology (i.e. Simon, 1969; Basalla, 1988; Kelly, 1992; Diamond, 1999; Saviotti, 2006; Ziman, 2000; Frenken, 2006; Arthur, 2009). Recently the evolutionary model has also been applied in different ambits like fiction and music (Mellor, 1990), art (Dutton, 2009) ${ }^{8}$, narrative (Boyd, 2009) and literary genres 
(Moretti, 2005).

\section{Evolution: media extinction/survival}

Looking at the media ecosystem from an evolutionary perspective means bringing up new concepts and questions for discussion. Let's think about the concept of extinction: Can media become extinct? The answer seems to be affirmative: the history of media is full of technological fossils, from papyrus to the telegraph. But do media really become extinct, or do they, as McLuhan postulated, survive in the content of the 'new' media? If we consider a media a technological support (e.g. the book) that activates a practice (e.g. reading) made possible by a signification system (e.g. verbal language), then these questions about media extinction could be resituated in a more complex context. Let's see a couple of examples to illustrate these questions.

The technological support of a media may become extinct - e.g. the electromechanical device of the telegraph - but the practice or the signification system may survive in other supports - e.g. the 'telegraphic' style of SMSs or tweets. Typewriters are also a good example of extinction and at the same time continuity: they have almost disappeared but the QWERTY keyboard has survived in PCs, notebooks and tablets. Similarly, the page - considered as a basic unit of textual interfaces and as a measurement of documenting or recording quantity - has been used for the last 2,000 years and can still be found in handwritten manuscripts, printed books and the web (webpage). Codex books are extinct, but the page and the gestures of using the page, like turning the page, are still 
alive on our interactive screens. On the other side, a technological support may survive the extinction of a signification system (e.g. Etruscan, a language spoken in central Italy, became extinct in $100 \mathrm{AD}$, but walls, coins and portable objects continued to be used as a writing support for centuries). These questions about media extinctions are a hot topic nowadays when scholars from different countries are discussing about the possible end of mass media (Missika, 2007; Carlón \& Scolari, 2009, Katz \& Scannell, 2009).

The famous Darwinian struggle for survival, like the rest of the ecological and evolutionary metaphors, cannot be automatically applied to media evolution. More than an individual struggle for survival, in media ecology it is possible to identify a collective struggle in which different actors - consumers, producers, political institutions, economic groups, technology companies, etc. - condition the development of a media.

If biological evolution and survival is based on a combination of natural selection (Darwin, 1975), self-organization (Kauffman, 1998, 2000) and symbiotic processes (Margulis, 1998), media emergence, survival and evolution are founded on the relationships established between technologies, subjects and institutions in the media ecology. For example, the emergence and survival of the radio in the 1920 s was made possible by the relationships established between many varying factors: devices like the transmitter and the vacuum-tube, wireless communication researchers like T. Edison and G. Marconi, sponsors, concepts like Edison's etheric force, radio amateurs, educational institutions, the U.S. Navy, the U.S. Government, major corporations like the American Telephone \& Telegraph Company, General Electric, and Westinghouse, and, last but not least, audiences. 
The same may be said about other media like television in the 1950s or the World Wide Web in the 1990s.

However in the technological realm it is not always the best device - in the sense of the most stylish, functional or highly developed - that survives. One well-known example of the survival of the worst option in the media field is the VHS format after the war against the Betamax system in the late 1970-80s. The same could be said for the QWERTY keyboard: it was created to reduce the typing speed and thus avoid mechanical typewriters breaking down in the nineteenth century. According to Gould QWERTY's 'fortunate and improbable ascent to incumbency occurred by a concatenation of circumstances, each indecisive in itself, but all probably necessary for the eventual outcome' (1987: 73). A specific configuration of the network determined by the different actors involved in this new technology - typewriter producers, typing schools, publishers of typing manuals, secretaries, etc. - has led to the survival of the QWERTY keyboard until today.

\section{Evolution: bursts of new media}

If we talk about evolution we can also incorporate another concept into our discourse: punctuated equilibrium. This theory, introduced by Eldredge \& Gould (1972), proposes that species experience little evolutionary mutations for most of their history, but when evolution occurs it is localized in rapid events of branching speciation. This idea, originally developed for organic species, has been applied to other fields; for example, Moretti's 
research into the evolution of literary genres between 1740 and 1900 determined six major bursts of creativity in the late 1760s, early 1790s, late 1820s, 1850, early 1870s, and midlate 1880s. Instead of progressively changing over time 'the system stands still for decades, and is then "punctuated" by brief bursts of invention: forms change once, rapidly, across the board, and then repeat themselves for two-three decades: "normal literature", we could call it, in analogy to Kuhn's normal science' (Moretti, 2005: 18-19). ${ }^{9}$

Media ecologists have also applied the concept of punctuated equilibrium to the evolution of media (Levinson, 1979) and language (Logan, 2007). According to Logan the evolution of the notated languages of writing, speech, mathematics, science, computing and the Internet have all taken place within approximately the past five thousand years, a time frame 'in which the biological evolution of Homo Sapiens would have been insignificant' (2007: 155-156). Currently, in the beginning of the $21^{\text {st }}$ century, we are witnessing an explosion of new media species (webpages, blogs, wikis, social networks, videogames, mobile applications, etc.). Could this phenomenon be considered an example of punctuated equilibrium in the long evolution of media? To answer this question we should re-write the history of human communication from oral culture to iPads taking into account the periods of extinctions and explosions of new media. ${ }^{10}$

\section{Intermedia relationships: coevolution}

The analysis of the relationships between media - a subject that, as I have demonstrated in the first section, has been an item on the media ecology research agenda 
since the initial stages - could be expanded by developing a taxonomy of possible intermedia relations. In specific periods of their life, media can cooperate with each other, for example the cooperation between the railroad and the telegraph in the $19^{\text {th }}$ century or the contemporary synergies between cinema, videogames and the comic industry. These synergies do not only affect the production - i.e. the economic convergence (Grant \& Wilkinson, 2008; Staiger \& Hake, 2009; Dwyer, 2010) - but also the narrative, aesthetic and consumption practices of all the media involved. This process could be considered to be an example of intermedia coevolution.

In the biological realm parasitism can also generate coevolutionary processes. In our case we could analyze the coevolution between a 'host media' species (the World Wide Web) and its 'media parasites' (Twitter, Facebook, Google, etc.), or, in traditional media, the coevolution of comic stripes inside newspapers at the end of the $19^{\text {th }}$ century. Media may also establish predator-prey interactions: in the 1950s television preyed on cinema and radio contents, aesthetics and audiences, and today new media are doing the same with traditional broadcasting media. Media ecologists should analyze these and other possible relations and propose a precise classification of intermedia relations in their research agenda.

As we can appreciate, coevolution is a key concept for media ecology. ${ }^{11}$ In the biological realm coevolution can occur at multiple levels, from microscopic - correlated mutations between amino acids in a protein - to macroscopic level - correlated mutations between species. In a coevolutionary relation each of the species exerts selective pressures 
on the others, and thereby they affect each others' evolution. From the perspective of an ecology of media we can identify different coevolutionary processes:

- Intermedia coevolution: This is the analysis of the correlated mutations in two or more media; for example, the book has coevolved with other media like recorded music. At the beginning of the $20^{\text {th }}$ century music adopted a production/distribution model from books (content could be bought in an independent support - the vinyl disc and the book - in specific stores); at the beginning of the $21^{\text {st }}$ century digital music is imposing a new production/distribution model on digital books (from the iTunes Store to the iBook Store).

- Human-media coevolution: This is the analysis of the correlated mutations between media and their consumers. If every text constructs its own reader $(E c o, 1979)$ and every interface constructs its own user (Scolari, 2004, 2009b), then every media constructs its own consumer: A $20^{\text {th }}$ century book-reader would find it very difficult to read a $13^{\text {th }}$ century codex; and a TV serial from the 1970 s - if compared with the highly complex contemporary audiovisual productions - seems slow and boring to young viewers, etc. (Scolari, 2009c). How do consumers (readers, viewers, users) coevolve with their media? How do media coevolve with their consumers? These mutual and interactive adaptation processes could expand the media ecology research agenda by suggesting new questions and hypotheses.

As we can see, the exploration of the evolutionary dimension of media poses new challenges for communication research. Concepts like extinction, punctuated equilibrium, 
evolution, and coevolution enrich the media ecology dictionary and expand the range of the possible theoretical and empirical interventions in the field.

\section{Interface}

The term interface was introduced by J. T. Bottomley in Hydrostatics (1882) to identify a 'separation surface' between two liquids. But the interface does not only separate: it allows certain elements (molecules, particles, etc.) to pass through it like in an osmosis process. The concept of interface has been employed in a broad range of discourses and contexts. In The Gutenberg Galaxy McLuhan described the Renaissance as the interface between the Middle Age and Modern times (1962: 141), big corporations love talking about the 'company-client interfaces', and we should not be surprised if one day we find pedagogues talking about the 'teacher-student interface'. Any communicative interchange that takes place in a specific space belongs to the interface universe (Scolari, 2004, 2009b).

The concept of interface has a different meaning for computer scientists, engineers and technicians, who talk about the 'USB interface' or the 'serial interface'. For them the interface is a physical connection, a bridge between two or more devices, for example between the printer and the computer (Scolari, 2004). From this perspective any technological device is an interface. For example, an automobile is a complex interface that integrates an engine, four wheels, electronic and electrical components, seats, etc. The same may be said about a microwave oven, an airplane or a building. In these cases we can talk 
about a technology-technology interface.

The interface is also the place where consumers and technology get in contact and interact with each other (Norman, 1998). The interface of a traditional book is composed by a set of printed cellulose sheets, navigation devices (page numbers, indexing system, summary, etc.), the paratexts that surround the text (cover, dedication, title, opening information, author's biographical note, etc.), and, obviously, the main organic component of the interface: the reader. The same may be said for a television (an interface made of electronic components, a screen, an antenna or cable connection, a remote control, a TV guide and a viewer), a transistor radio or an iPod. In these cases we can talk about a humantechnology interface.

\section{Media interfaces}

In this context we could rethink media ecology from the perspective of an integrated theory of the interface. Every media has an interface (human-technology interface), and at the same time every media is an interface (technology-technology interface). Let's look at an example: an iPhone establishes an interface with the user for interacting with it, but at the same time, it is a complex interface that integrates components like a touch-screen, a microprocessor, telecommunication technology, accelerometers, motion, magnetic, pressure and temperature sensors, etc. I consider this double dimension of the interface a basic element for expanding the ecological (synchronic) and evolutionary (diachronic) metaphor in media ecology. 
From the ecological perspective, it could be said that the interface is the place where readers/viewers/users interact with the media; in other words, the interface is the minimal expression of the environment that media ecologists have been describing and analyzing for the last fifty years. Within an evolutionary approach we could say that the interface is the place where the evolution of the media is negotiated. The dialectic interactions and exchanges between readers/viewers/users and the media model their coevolution (Scolari, 2004). But the interface is also the place where media interact with each other and coevolve, i.e. the interface between comic and video game, or between television and cinema. As we can see the interface is a key concept for our theoretical discourse because it integrates the two interpretations of media ecology.

But the interface is not only the place where a media connects with other media and the human users. As I indicated at the end of the first section, both media ecology metaphors (media as environment, media as species) could be integrated into a broader context very close to the Actor-Network Theory and the Social Construction of Technology. In this interdisciplinary context in which media ecology dialogues with the ANT and SCOT, the interface could also be considered the place where political, social and economic actors express and interact with technological devices and humans. From this perspective the interface is a deeply political device that expresses social, economic and cultural forces.

From an evolutionary perspective the interface is the place where the evolution of a media or technology is defined. As we have already seen, the dialectics between producers, 
consumers, devices and institutions are the most important engine for the emergence and survival of media and technological devices. In 1980 Apple presented a revolutionary computer with mouse and graphic interface: the Apple Lisa. One year later Xerox introduced the Xerox Star, a personal computer that also included mouse and graphic interface. Both machines were a commercial failure. In 1984 another computer with mouse and graphic interface, the Apple Macintosh, survived. Why? The combination of the Apple Macintosh, the Apple Laser Writer, the Encapsulated PostScript (EPS) language and software like Aldus PageMaker created a new technological interface that sparked the desktop publishing (DTP) revolution in the mid-1980s (Lévy, 1990). Something similar happened with the Apple Newton in the late 1990s, an extinct antecessor of the successful iPad of the 2010s: the media ecology was not 'ready' for the new technological species.

In a few words: the study of interfaces could be considered the micro-level of media ecology analysis, the minimal unit of analysis, like the sign for linguistics or the gene for genetics. Concepts like system in the 1950s, structure in the 1960s, or text in the 1980s left a deep imprint on social sciences conversations. Maybe interface will be the key concept of the new generation of media ecologists.

\section{Hybridizations}

The interface is the place where media dialogues confront and contaminate each other. From an evolutionary (diachronic) perspective the contamination between media should be considered a coevolutionary process, e.g. in the 1950s radio contents, formats, 
business-models and reception practices were transferred to television, and then later radio had to adapt to the new conditions of the media ecosystem after television had become consolidated (Fornatale \& Mills, 1980). However, if we consider the contaminations from an ecological (synchronic) perspective then we must talk about hybridizations or remediations (Bolter \& Grusin, 2000). ${ }^{12}$ On different occasions McLuhan spoke about the 'interpenetration of one medium by another' (2003: 76) or the 'cross-fertilization' between systems, for example print with the steam press, or radio with movies (2003: 58-59). According to McLuhan the crossings and hybridizations of the media release 'great new force and energy as by fission or fusion' and, at the same time, generate a 'new form' (2003: 72-80).

Media hybridize at different levels and in different ways. As we have seen, a device developed for typewriters (the QWERTY keypad) is applied in digital tablets, and a text unit born in handwritten books (the page) is still useful for identifying the content in the World Wide Web (webpages). Hybridizations may appear in the content of media - for example when television dramas in the 1950s adopted the narrative models of the radio drama - or in their interaction devices - for example, the digital music players reproduces the 'buttons' of traditional electronic players. The remediations analyzed by Bolter \& Grusin (2000) could be improved by developing a more complex map of hybridizations based on a media ecology / evolution theoretical framework.

Media coevolve and hybridize each other. These two processes can be seen as two sides of the same coin: if we think in time, we'll discover coevolution; if we think in space, 
we'll see hybridization. An expansion of the ecological and evolutionary metaphor should include an exploration of these dimensions of the dynamics between media. In this framework the concept of interface could be - once again - a helpful theoretical category for analyzing the intermedia relations and developing taxonomies of the possible links different media could establish with each other.

\section{Conclusions and implications}

Working with analogies can be problematic. Some biological laws and principles do not allow a technological translation. Human bodies are not machines, in the same way that interfaces are not living entities. Biological analogies can suggest interesting problems, but sometimes they do not provide good answers; they therefore must be approached with caution due to the differences between the organic and technological worlds. A one-to-one correspondence between biological and technological domains is impossible and can even be dangerous (Basalla, 1988; Gould, 1991). Transferring categories from one domain to another is very useful for finding a descriptive model and formulating new questions and problems, but the answers to these questions are very often outside the analogy. However, when a research field is taking its first steps, analogies offer new insights and useful perspectives. This is the situation media ecology is in right now.

In this article I have briefly described media ecology in the context of a general application of biological, evolutionary and ecological models in the social sciences in the second half of the $20^{\text {th }}$ century. In my view, media ecologists have interpreted the 
ecological metaphor in two different ways: 1) media ecology as an environment, and 2) media ecology as an intermedia relationship. The main theoretical contributions of the article are: 1) the expansion of the ecological metaphor based on three concepts: evolution, interface and hybridization; 2) the placement of the concept of interface at the center of the media ecology approach (that is, the interface as the minimum unit of analysis of media ecology); 3) the proposal to consider media history from an evolutionary perspective, and include categories like media extinction, media survival, punctuated equilibrium and coevolution; and 4) the proposal to expand media ecology interlocutors by including society-technology theories like ANT or SCOT, and other approaches based on the complexity theory.

The concept of evolution creates a strong theoretical framework for studying the history of media, a key research subject for media ecology. Applying the evolutionary metaphor enriches the theoretical conversations on media ecology by including new concepts. Moreover, within this context media researchers could rethink the whole history of technologically mediated communication by identifying and analyzing specific moments characterized by media extinction or new media explosions.

The concept of coevolution, as I have demonstrated in a couple of examples, can provide media scholars a useful theoretical category for reframing the relationships between different media (intermedia coevolution) or between subjects and media (humanmedia coevolution).

As I have showed in the last section, the concept of interface could be considered the 
minimal unit of analysis for media ecology; it is a flexible and useful concept that can be applied both at the macro and micro levels of analysis. As the contemporary mediasphere is characterized by the emergence of new interactive media, the concept of interface is also a valuable category if media researchers want to develop an interdisciplinary conversation with fields like human-computer interaction (HCI) or interaction design. Finally, the analysis of media hybridizations is fundamental for understanding the appearance of new 'loanblended' species like the iPhone (iPod + mobile phone) and for studying the convergence processes.

A final reflection on media ecology, technology and determinism: As every communication scholar knows, the media ecology tradition and thinkers such as McLuhan, Postman, and Innis have been found guilty of technological determinism. Some of McLuhan's aphorisms - like 'the medium is the message'- suggest that he had a highly deterministic view of human-technology relationships. However, media ecologists have always defended and promoted a dialectic and transactional approach to media and culture (Strate, 2008). Placing the concept of interface at the center of the media ecology theoretical discourse means reinforcing and highlighting the complex dialectics between subjects, media and social forces, eradicating at the same time any possibility of determinism.

The explorations that I propose in this text could also be useful for establishing new scientific interlocutors for media research in general and media ecology in particular. If we consider the media ecosystem as a network of technologies, producers, consumers and 
social forces, we could imagine interesting theoretical conversations with interlocutors like the Actor-Network Theory (Latour, 1987, 2005; Law \& Hassard, 1999), the Social Construction of Technology (Hughes, 1983; Bijker, Hughes \& Pinch 1987; Bijker \& Law, 1992; Bijker, 1997) or the scholars focused on the evolution of technology (Basalla, 1988) and the emergence and complexity of new technology (Arthur, 2009). In this context media ecology could also be an epistemological interface for holding new theoretical conversations between different scientific fields and traditions.

\section{References}

Arthur, B. (2009). The Nature of Technology: What It Is and How It Evolves. New York, NY: Free Press.

Barabási, A.-L. (2010) Bursts: The Hidden Pattern Behind Everything We Do. New York, NY: Dutton Books.

Basalla, G. (1988). The Evolution of Technology. New York, NY: Cambridge University Press.

Bijker, W. \& Law, J. (Eds.) (1992). Shaping Technology / Building Society. Studies in Sociotechnical Change. Cambridge, MA: MIT Press.

Bijker, W. (1997). Of Bicycles, Bakelites, and Bulbs. Toward a Theory of Sociotechnical Change. Cambridge, MA: MIT Press.

Bijker, W., Hughes. T. \& Pinch, T. (1987). The Social Construction of Technological 
Systems. New Directions in the Sociology and History of Technology. Cambridge, MA: MIT Press.

Bolter, J. D. \& Grusin, R. (2000) Remediation: Understanding New Media. Cambridge, MA: The MIT Press.

Borges, J. L. (1964). Kafka and his Precursors. In Labyrinths, pp. 199-201. New York, NY: New Direction Publishing Corporation.

Bottomley, J. T. (1882). Hydrostatics. London, UK: William Collins.

Boyd, B. (2009). On the Origin of Species. Evolution, cognition, and fiction. Cambridge, MA: The Belknap Press of the Harvard University Press.

Carey, J. (1989) Communication as Culture: Essays on Media and Society. New York, NY: Routledge.

Carlón, M. \& Scolari, C. (Eds.) (2009). El Fin de los Medios Masivos. El comienzo de un debate, Buenos Aires, Argentina: La Crujía.

Christiansen, M. (1994). Infinite languages finite minds: Connectionism, learning and linguistic structure. Unpublished doctoral dissertation, Centre for Cognitive Studies, University of Edinburgh, UK.

Christiansen, M. H., Dale, R., Ellefson, M. \& Conway, C. (2002). The role of sequential learning in language evolution: Computational and experimental studies. In A. Cangelosi \& D. Parisi (Eds.), Simulating the Evolution of Language, pp. 165/187. London, UK: Springer-Verlag.

Dann, C. (1999). From Earths' Last Islands. The global origins of Green politics. PhD 
Thesis, Lincoln University. Retrieved 15 May 2011 from:

http://hdl.handle.net/10182/1905

Darwin, C. R. (1975). The Origin of Species by Means of Natural Selection, or the preservation of favoured races in the struggle for life. Harmondsworth, UK: Penguin Books.

DeFleur, M. L. \& Ball-Rokeach, S. (1989). Theories of mass communication (5th ed.). White Plains, NY: Longman.

Diamond, J. (1999). Guns, Germs, and Steel: The Fates of Human Societies. New York, NY: W.W. Norton.

Dimmick, W.J. (2003). Media Competition and Coexistence - the Theory of the Niche. Mahwah, NJ: LEA Publishers.

Dutton, D. (2009). The Art Instinct: Beauty, Pleasure, and Human Evolution. New York, NY: Oxford University Press.

Dwyer, T. (2010). Media Convergence. Maidenhead, UK: Open University Press.

Eldredge, N. \& Gould, S. J. (1972). Punctuated equilibria: an alternative to phyletic gradualism. In T.J.M. (Schopf, ed.) Models in Paleobiology, 82-115. San Francisco, CA: Freeman Cooper.

Flayhan, D. (2001) Cultural Studies and Media Ecology: Meyrowitz's Medium Theory and Carey's Cultural Studies. Atlantic Journal of Communication, 9(1), 21-44. DOI: $10.1080 / 15456870109367396$

Fornatale, P. \& Mills, J. (1980). Radio in the television age. Woodstock, NY: Overlook. 
Frenken, K. (2006). Innovation, Evolution and Complexity Theory. Chetelnham, UK:

Edward Elgar.

Gencarelli, T. (2000) The intellectual roots of media ecology in the work and thought of Neil Postman. Atlantic Journal of Communication, 8(1), 91-103. DOI: $10.1080 / 15456870009367381$

Gitelman, L. (2006). Always Already New. Media, History, and the Data of Culture. Cambridge, MA: MIT Press.

Gitelman, L. \& Pingree, G. (Eds.) (2003). New Media, 1740-1915. Cambridge, MA: MIT Press.

Gould, S. J. (1987). The Panda's Thumb of Technology. Natural History 96 (1), 14-23.

Gould, S. J. (1991). Bully for Brontosaurus. New York, NY: W.W. Norton.

Grant, A. \& Wilkinson, J. (Eds.) (2008). Understanding Media Convergence. New York, NY: Oxford University Press.

Hughes, T. (1983). Networks of Power: Electrification in Western Society, 1880-1930. Baltimore, MD: The Johns Hopkins University Press.

Innis, H. (2003). The Bias of Communication. Toronto: University of Toronto Press (orig. ed.: 1951).

Johnson, D. \& Wetmore, J. (2009). Technology and Society. Building our Sociotechnical Future. Cambridge, MA: The MIT Press.

Katz, E. \& Scannell, P. (Eds.) (2009). The End of Television? Its Impact on the World (So Far). The Annals of the American Academy of Political and Social Science, 625: 1. 
Kauffman, S. (1995). At Home in the Universe: The Search for Laws of Self-Organization and Complexity. New York, NY: Oxford University Press.

Kauffman, S. (2000). Investigations. New York, NY: Oxford University Press.

Kelly, K. (1992). Out of Control: The New Biology of Machines, Social Systems, and the Economic World. New York, NY: Pantheon.

Kuhn, T. S. (1962). The Structure of Scientific Revolutions. Chicago, IL: University of Chicago Press.

Lakoff, G. \& Johnson, M. (1980). Metaphors we live by. Chicago, IL: University of Chicago Press.

Latour, B. (1987). Science in Action: How to Follow Scientists and Engineers Through Society. Milton Keynes, UK: Open University Press.

Latour, B. (2005). Reassembling the Social: An Introduction to Actor-Network-Theory. New York, NY: Oxford University Press.

Law, J. \& Hassard, J. (Eds.) (1999). Actor Network Theory and After. Oxford and Keele: Blackwell and the Sociological Review).

Lehman-Wilzig, S. \& Cohen-Avigdor, N. (2004). The natural life cycle of new media evolution: Inter-media struggle for survival in the Internet age. New Media Society, 6(6): 707-730. DOI: $10.1177 / 146144804042524$

Levinson, P. (1997). The Soft Edge: A natural history and future of the information revolution. New York, NY: Routledge.

Levinson, P. (1979). Human replay: A theory of the evolution of media (Doctoral 
dissertation, New York University, 1979). Dissertation Abstracts International, 40, 03A: 1136.

Levinson, P. (1999). Digital McLuhan: A Guide to the Information Millennium. New York, NY: Routledge.

Lévy, P. (1990) Les Technologies de l'Intelligence. Paris: La Découverte.

Logan, R. (2004). The Sixth Language: Learning a Living in the Internet Age. Caldwell, NJ: Blackburn Press.

Logan, R. (2007a). The Extended Mind. The Emergence of Language, the Human Mind, and Culture. Toronto: University of Toronto Press.

Logan, R. (2007b). The biological foundation of media ecology. Explorations Media Ecology, 6, 19-34.

Lum, C. M. K. (Ed.). (2006). Perspectives on culture, technology, and communication: The media ecology tradition. Cresskill, NJ: Hampton Press.

Margulis, L. (1998). Symbiotic Planet (A New Look at Evolution), New York, NY: Basic Books.

Marvin, C. (1988). When Old Technologies Were New: Thinking about Electric Communication in the Late Nineteenth Century. New York, NY: Oxford University Press.

McLuhan, M. (1962). The Gutenberg Galaxy: the making of typographic man. Toronto: University of Toronto Press.

McLuhan, M. (1964). Understanding Media: The Extensions of Man. Toronto: University 
of Toronto Press.

McLuhan, M. (1969). Playboy Interview: Marshall McLuhan - A candid conversation with the high priest of popcult and metaphysician of media. Playboy (March); reprinted in McLuhan, E. \& Zingrone, F. (Eds.) (1995). Essential McLuhan, pp. 233-69. New York, NY: Basic Books. Retrieved 20 January 2011 from: HYPERLINK "http://www.nextnature.net/?p=1025" http://www.nextnature.net/?p=1025

McLuhan, M. (2003). Understanding Me: Lectures \& Interviews. McLuhan, S. \& Staines, D. (Eds). Cambridge, MA: MIT.

McLuhan, M. \& McLuhan, E. (1992). Laws of Media: The New Science, Toronto: University of Toronto Press.

Mellor, D. H. (1990). Ways of Communicating. Cambridge, MA: Cambridge University Press.

Meyrowitz, J. (1985). No Sense of Place: The Impact of Electronic Media on Social Behavior. New York, NY: Oxford University Press.

Meyrowitz, J. (2003). Canonic Anti-Text: Marshall McLuhans's Understanding Media. In E. Katz, J. Durham Peters, T. Liebes \& A. Orloff (Eds.). Canonic Texts in Media Research, pp. 191-212. Cambridge, UK: Polite Press.

Missika, J.-L. (2006). La fin de la télévision. Paris: Éditions du Seuil.

Moretti, Franco (2005). Graphs, maps, trees: abstract models for a literary history. London, UK: Verso.

Nardi, B. \& O’Day, V. (1999). Information Ecologies. Using Technology with Heart. 
Cambridge, MA: MIT Press.

Noelle-Neumann, E. (1993). The Spiral of Silence: Public Opinion - Our Social Skin.

Chicago, IL: University of Chicago Press.

Norman, D. (1998). The Design of Everyday Things. Cambridge, MA: MIT Press.

Nystrom C. (1973). Towards a Science of Media Ecology: The Formulation of Integrated Conceptual Paradigms for the Study of Human Communication Systems. Doctoral Dissertation, New York University.

Odum, E. P. (1964). The New Ecology. BioScience, 14: 7, 14-16.

Odum, E. P. (1977). The emergence of ecology as a new integrative discipline. Science, 195:4284, 1289-1293. DOI: 10.1126/science.195.4284.1289

Ortony, A. (1979). Metaphor and Thought. Cambridge, UK: Cambridge University Press.

Otis, L. (1999). Membranes. Metaphors of Invasion in Nineteenth-Century Literature, Science, and Politics. Baltimore: The Johns Hopkins University Press.

Postman, N. (1985). Amusing Ourselves to Death. New York, NY: Penguin.

Postman, N. (1970). The Reformed English Curriculum. In A.C. Eurich (Ed.) High School 1980: The Shape of the Future in American Secondary Education (1970). Retrieved 15 November 2010 from: http://www.media-ecology.org/media_ecology

Postman, N. (1998). Five Things We Need to Know About Technological Change. Conference in Denver, CO. Retrieved 15 November 2010 from: http://www.mat.upm.es/ jcm/neil-postman--five-things.html

Ramos, L. (2000). Understanding Literacy: Theoretical Foundations for Research in Media 
Ecology. Atlantic Journal of Communication, 8(1), 46-55.

DOI:10.1080/15456870009367378

Saviotti, P. (1996). Technological Evolution, Variety and the Economy. Chetelnham, UK: Edward Elgar.

Scolari, C.A. (2004). Hacer clic. Hacia una sociosemiótica de las interacciones digitales. Barcelona: Gedisa.

Scolari, C.A. (2008). Hipermediaciones. Elementos para una teoría de la comunicación digital interactiva. Barcelona: Gedisa.

Scolari, C. A. (2009a). Mapping conversations about new media: the theoretical field of digital communication. New Media \& Society, 11(6), 943-964. DOI:

$10.1177 / 1461444809336513$

Scolari, C.A. (2009b). The Sense of the Interface: Applying semiotics to HCI research. Semiotica, 177, 1-27. DOI: 10.1515/semi.2009.067

Scolari, C.A. (2009c). The Grammar of Hypertelevision: An Identikit of Convergence-Age Fiction Television (Or, How Television Simulates New Interactive Media). Journal of Visual Literacy, 28: 1, 28-49.

Shannon, C. E., \& Weaver, W. (1949). The Mathematical Theory of Communication. Urbana, IL: University of Illinois Press. Reprinted (and repaginated) 1963.

Simon, H. (1969). The Sciences of the Artificial. Cambridge, MA: MIT Press, Staiger, J. \& Hake, S. (Eds.) (2009). Convergence Media History. New York, NY: Routledge. 
Strate, L. (2004). A Media Ecology Review, Communication Research Trends. 23:2, 3-48.

Strate, L. (2007). Understanding a Man in Time: James W. Carey and the Media Ecology Intellectual Tradition. Critical Studies in Media Communication, 24: 2, 177 - 180. DOI: $10.1080 / 07393180701262925$

Strate, L. (2008). Studying Media As Media: McLuhan and the Media Ecology approach. MediaTropes eJournal, 1, 127-142.

Wolf, M. (1985). Teorie delle comunicazioni di massa. Milan: Bompiani.

Ziman, J. (ed.). Technological Innovation as an Evolutionary Process. Cambridge, MA: Cambridge University Press. 


\section{Footnotes}

${ }^{1}$ In September 1981 - McLuhan passed away in December 1980 - The Journal of Communication published a special section under the title The Living McLuhan that included articles written by Walter Ong, Paul Levinson, James Carey, etc. However, the classic monographic issue Ferment in the Field of The Journal of Communication (1983) and the following Ferment in the Field I and II (1993) overlooked media ecology (Lum, 2006: 3).

${ }^{2}$ For an analysis of McLuhan's revival in the 1990s see Levinson (1999) and Meyrowitz (2003). For a panorama of media ecology tradition see Lum (2006) and Strate $(2004,2008)$.

${ }^{3}$ In this article theories are considered as if they were conversations. Scientific conversations emerge in an organizational environment made up of universities, research centers, journals and conferences (Scolari, 2008, 2009a). In this interpretative context the extensive citation of authors is necessary to identify their key concepts, metaphors and conceptions. However, I'll try to reduce these citations to a minimum to facilitate the exposition.

\footnotetext{
${ }^{4}$ Although it is not the objective of this article to discuss the internal disputes between media ecologists, we must recognize that the field has been crossed by contradictions and differences. Sometimes the internal disagreements have taken a moral line: Postman was considered a moralist while McLuhan defended the moral
} 
neutrality of media analysis. Postman was very clear on this point: 'I think there is considerable merit in McLuhan's point of view about avoiding questions of good and bad when thinking about media. But that view has never been mine. To be quite honest about it, I don't see any point in studying media unless one does so within a moral or ethical context' (Postman, 2000). Carey is known as one of the sharpest critics of McLuhan; Carey preferred the careful accumulation of detail and the identification of many interconnections in Innis's scholarship to McLuhan’s polemical generalizations (Strate, 2007). The attitude of media ecologists towards media evolution has also been contradictory: while scholars like Postman (1985) lamented the decline of the printed word, other researchers like Meyrowitz (1985) and Levinson (1997) were more enthusiastic about the arrival of electronic media (Ramos, 2000: 54) (see also (Gencarelli, 2000). As we can see, media ecology, like any other scientific field, has been crossed by contradictions and differences. However, media ecologists agree on many points, from the criticism of the transmission view of communication to the development of an environmental vision of media, culture and technology. After all, these internal tensions demonstrate the vitality of the media ecology conversations and the effervescence of a scientific field that is still 'under-construction'.

5 'Metaphors matter. People who see technology as a tool see themselves controlling it. People who see technology as a system see themselves caught up inside it. We see technology as a part of an ecology, surrounded by a dense network of 
relationships in local environments. Each of these metaphors is "right", in some sense; each captures some important characteristics of technology in society. Each suggests different possibilities for action and change' (Nardi \& O'Day, 1999: 27). ${ }^{6}$ According to Dimmick (2003) 'like the biologist, the researcher interested in the (...) media cannot appeal to universal laws like those of chemistry or classical physics (...) Like the biologist, who also studies complex living systems, the social scientist inhabits a world where prediction is difficult at best, and explanation must be won without recourse to causal laws' (2003: 1).

${ }^{7}$ The botanist Arthur Roy Clapham coined the term ecosystem in the 1930s. If we represent the relationships of the elements inside the ecosystem the emerging picture would resemble a bird's nest or a spaghetti diagram: a complex set of links connecting nodes. In other words, the ecosystem is a network of relationships between elements inside an environment.

${ }^{8}$ For Dutton 'it is time to look at the arts in the light of Charles Darwin's theory of evolution [...] Recent years have seen immensely productive applications of Darwinian ideas in anthropology, economics, social psychology, linguistics, history, politics, legal theory, and criminology, as well as the philosophical study of rationality, theology and value theory' (2009: 1-2).

${ }^{9}$ For more examples of bursting phenomena see Barabási (2010).

${ }^{10}$ This evolutionary vision of media history could complement and provide a broader framework for specific, old or extinct media analysis (Gitelman \& Pingree, 
2003; Gitelman, 2006; Marvin, 1988).

${ }^{11}$ The concept is also a key-element of Logan's research dedicated to the coevolution of culture and language (Logan, 2007). Also for Nardi and O'Day 'the social and technical aspects of an environment coevolve. People's activities and tools adjust and are adjusted in relation to each other, always attempting and never quite achieving a perfect fit' (1999: 53).

${ }^{12}$ In the context of a theory of new media, Bolter \& Grusin (2000) expanded another one of McLuhan's aphorisms - 'the content of any medium is always another medium' (2003: 19) - when they introduced the concept of remediation: 'We call the representation of one medium in another remediation [...] (this) is a defining characteristic of the new digital media [...] We can identify a spectrum of different ways in which digital media remediate their predecessors, a spectrum depending on the degree of perceived competition or rivalry between the new media and the old' (2000: 45). See also Strate (2008). 